\title{
QUANTIFYING FACTORS AFFECTING MNES' HUMAN RESOURCE MANAGEMENT: EVIDENCE FROM AN EMERGING ECONOMY AND IMPLICATIONS FOR HR MANAGERS
}

\author{
Chris I. Enyinda \\ Ajman University, UAE \\ Maria Jade Catalan-Opulencia \\ Ajman University, UAE \\ Mervyn Misajon \\ Ajman University, UAE \\ Gurumurthy Kalyanaram \\ City University of New York, USA
}

\begin{abstract}
Multinational enterprises (MNEs) conduct international business operations around the globe. For the MNEs, operating in today's global business environment demands that human resource departments be engaged in a variety of activities, including attracting talents, training and development, relocation, repatriation, among others. To contend with the increasing number of issues and challenges in international business environment, MNEs must strive to improve their international HRM strategies. As organizations manage subsidiaries across different countries, the approach to human resource management functions must consider the dictate of the local environment where the subsidiary has to operate in order to survive and prosper. The researchers applied a multi-criteria decision making algorithm known as the analytic hierarchy process (AHP) to model the challenges and issues that MNCs face as well as the factors impacting the HRM practices. The study explore the challenges by way of literature review and interview of some of the MNEs' C-level executives.
\end{abstract}

Keywords: Multi National Enterprises (MNEs), Human Resource Management, Emerging Economy, HR Managers.

DOI: http://dx.doi.org/10.15549/jeecar.v6i1.289

\section{INTRODUCTION}

Scullion (2005) attests that International Human Resource Management (IHRM) definitions have broadly concentrated on examining the HRM issues, problems, strategies, policies/practices in which MNEs pursue in relation to the internationalization of their business operations. Stahl and Björkman (2006) defined IHRM as all the issues related to the management of people in an international context, including human resource issues facing MNEs in different parts of their organizations, and comparative analyses of HRM in different countries. Scullion (2005) notes that IHRM is how MNEs manage their geographically distributed workforce in order to influence their 
HR resources for both local and global competitive advantage. IHRM is a branch of management studies that examines the design and effects of organizational human resource practices in cross-cultural contexts (Peltonen, 2006). Sparrow and Braun (2008) state that it is the actions HRM contributes to the process of globalization within multinational firms. In addition, it has been argued that IHRM implications that the process of internationalization has for the activities and policies of HRM (e.g. Dowling et al, 2008). The Human Resource function is indeed a critical dimension as it is given high importance by many existing companies, as well as various other programs to enhance the work environment (Sergio and Rylova, 2018)

Strategic HR decisions are characterized by more uncertainty in the decision- making process since future changes within the environment of organizations are uncertain (Purcell Ahlstrand, 1994). The role of HR department has become more central, particularly in the strategic decision-making process of the organization (Miller, 1989 and Analoui, 1998). It differentiates' between comparative HRM and IHRM where that comparative HRM (CHRM) explores the extent to which HRM differs between different countries or on occasions between different areas within a country or different regions of the world, such as North America, the Pacific Rim states or Europe (Brewster and Larsen, 2000). There are many issues regarding HR management in MNCs; however, a significant issue is the adaptation of the parent company's way of managing HR into different contexts in the corporations' subsidiaries operating in the host country (Evans et al., 2011; Rosenzweig, 2006). MNCs face a challenge to balance between going global and adapting locally (Ngo et al., 1998).

This exploratory paper attempts to investigate the challenges of managing HR in MNCs abroad. It analyzes the problems that MNCs faces in today's rapidly changing and competitive environment.

\section{Research Objectives:}

1.To identify and examine the issues and challenges that multinational organizations come across when managing their HR internationally.

2. To determine the extent to which MNCs adopt a uniform management approach in their international operations.

3.To discuss the difference of IHRM practices adoption between MNCs from emerging economies and those from developed markets.

4.To know the influence of internal and external environmental factors on IHRM strategy approach.

\section{REVIEW OF LITERATURE}

Globalization is playing role in the expansion of global business. The world economy is currently identified by the interactions that happen between somehow distinct national economies where it is believed that the outcomes are determined at the national level processes and operations (Harzing and Noorderhaven 2009; Rowley and Benson 2002). Moreover, it is believed that an MNC stays connected and rooted to its parent company national business system. However, companies face certain challenges when they operate globally. They become pressured to get the best out of their global activity as well as being able to react at a local or national level. Therefore, companies are facing a contradiction between thinking globally and acting locally (Harzing and Noorderhaven, 2009; Rowley and Benson, 2002; Smale, 2008).

\section{Challenges and Issues}

Foreign multinational corporations in Europe face cross national challenges when transferring and adapting their HRM operations mainly due to the unique European traditions and the presence of diverse nationalities within the region (Scullion and Brewster, 2002). There are many issues regarding $\mathrm{HR}$ management in MNCs; however, a significant issue is the adaptation of the parent company way of managing HR into different contexts in the corporations' subsidiaries operating in the host country. Also, MNCs are challenged as to how to deploy their human resources and manage them abroad in order to gain full benefits of scale as well as of scope as a MNC (Evans et al., 2011; 
Rosenzweig, 2006).

Some studies on HRM practices of some US multinational corporations subsidiaries operating in Europe reveal that global standardizing practices of the subsidiary usually follow the practices of parent country firm in the USA (Collings et al., 2008; Harzing, 1999). American MNCs tend to have strong control on their subsidiaries in Europe by transferring and applying their own ways and practices from the US to their European subsidiaries, but they also try to adapt locally to an extent (Collings et al., 2008; Ferner et al., 2004). In contrast localization in subsidiary hiring focuses on choosing employees of the host country nationals (HCN) for high positions rather than parent country national employees. According to Harzing (2001), 79.5\% of the managing directors working in US multinational corporations were HCNs, whereas in Germany the percentage of $\mathrm{HCN}$ in their foreign subsidiaries was $40.7 \%$ and $37.5 \%$ for Japanese MNCs.

\section{Country of Origin Effect on Strategy}

MNEs face a challenge to balance between going global and adapting locally. Leading edge HR practices, which have yielded high growth performance of companies in the Asia-Pacific region, serve valuable lessons in the practice of HR (McCartney, 2011). Reports show that most MNCs' operations have something from their home country origin. That might be due to subconscious decisions or choices that are affected by both cultural and institutional features from the home country of the MNCs or is due to some kind of cultural transfer by the people working within the corporation (Harzing \& Sorge, 2003). Similarly, Chew and Zhu (2002) stated that US and European Human Resource systems both influence and are influenced by the human resource management systems of East Asian firms.

\section{Influencing Factors}

MNC's management practices are affected by many external and internal factors. In particular, the host country's economic systems and developments as well as other associated factors such as market labor situation or inflation rates play a significant role in HRM like influencing the kind of staff qualification availability in a country (Kammel and Teichelmann, 1994; Cherrington, 1983; Hentze, 1989). The politicallegal environment affects MNC-'s because of the diverse employees and their national employment laws and legislation systems that impact the multinational organization directly (Gustaffson, 1990; Pieper, 1990); for instance, work councils/ employment contracts, and employee protection laws like maternity leave and tax systems. These factors influence the way employees are motivated, type of compensations given and personal development (Scherm, 1999). It is essential to understand the importance of social relationships within HRM.

The transmission of human resource management practices of multinational corporations to their subsidiaries shows that they mainly acquire hybrid methods by using push force when enforcing control from headquarters and pull force for compliance with the standards of host country in order to suit the new market (Rose \& Kumar, 2007).

\section{Managing IHR Globally}

According to Schuler et al. (2002), MNEs should go through certain strategies and specific functions to lower the effects of diversity when they operates globally. They further states that these functions are mainly the staffing policies, compensation policies, human resource planning, training and development, performance appraisal and a standardized international human resource management. All of these functions are essentials to help and coordinate the MNEs to do their business and manage their diverse human resources effectively in a different environment.

Moreover, compensating expatriates is essential and is argued to be as important as appraisal to gain the demanded international strategic objectives. According to Wong (2000) an international HR manager needs to address the following; assignment/ cost planning, selection of candidates, assignment terms and documentation conditions, culture and language training and other planning strategies that should be covered for international $H R$ planning. It is very important to train employees before sending them to another country. Through that employees are trained on personal 
security for them to stay safe which enables the employee to keep his/her psychological contract with the employer (Guest and Conway, 2001). The training and development of assigned employees to go internationally should be looked into a larger and broader frame that describes IHRM more systematically and theoretically accurately (Mendenhall et al. 2002).

According to Schuler et al. (1993) integrative framework of IHRM in MNEs, there should be a relationship between the internal operation and inter-unit linkage of an MNE. This looks into the internal operations as adding advantage by having policies and practices that are adapted to the subsidiary local market to gain the ultimate competitive advantage. On the other hand, the framework shows that although internal operations are important, there must be an inter-unit linkage of HR practices globally to connect the different subsidiaries of an MNE operating in different countries to gain efficiencies of scale and have a standardized strategy.

\section{METHODOLOGY}

The goal of this research paper is to determine the issues and challenges of managing human resources in multinational organizations since they are major issues that MNEs face nowadays. A multi-criteria approach proposed for this study is AHP. AHP allows decision-makers to model a complex problem in a hierarchical structure, showing the relationships of the overall goal, criteria (objectives) and alternatives. Due to its usefulness, AHP is widely used in both practitioner and academic research. Studies that have used AHP include supply chain management (e.g., Gaudesi and Borghesi 2006) and pharmaceutical risk management (Enyinda et al. 2009).

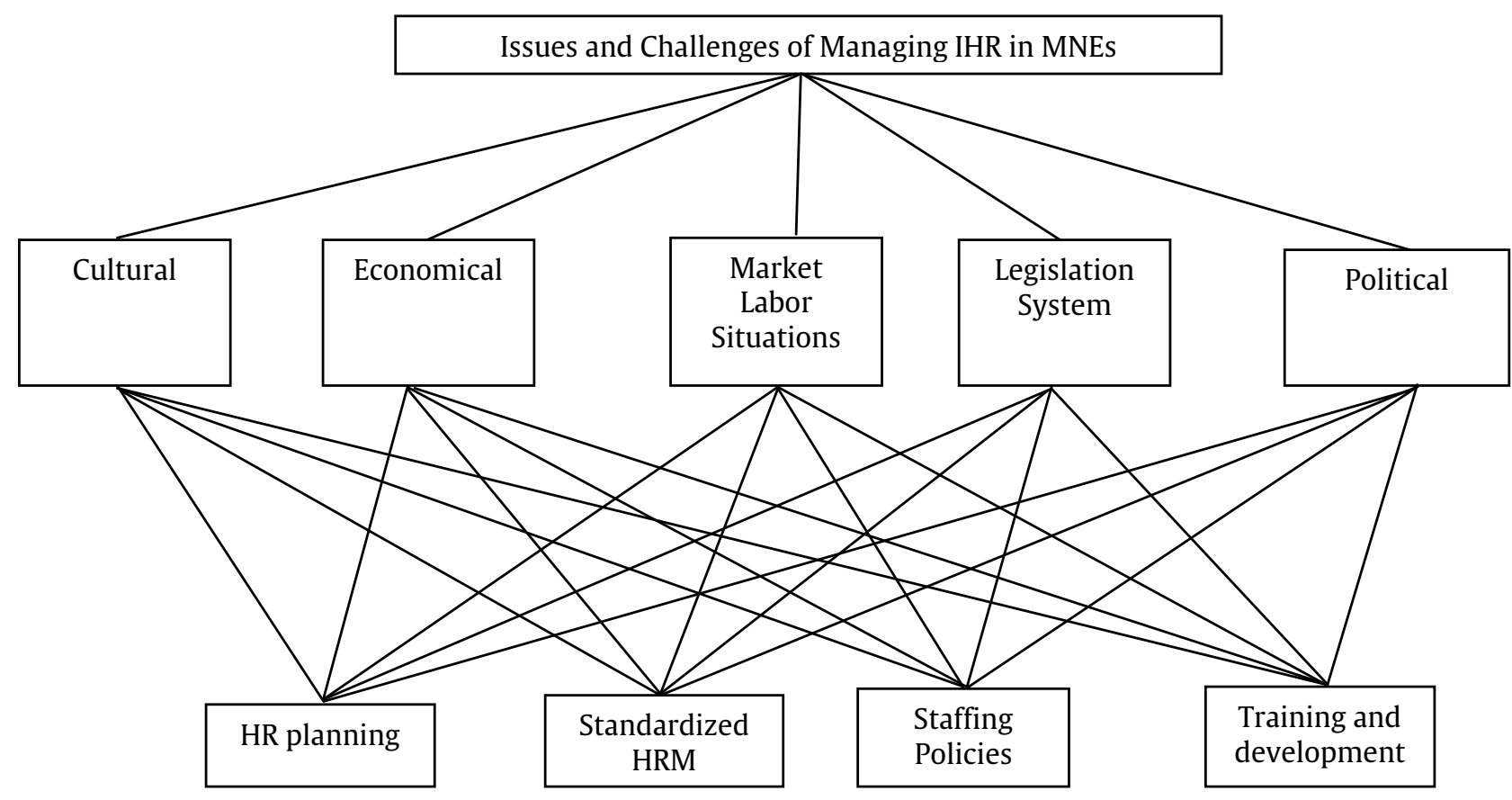

Figure 1. Decision Hierarchy of Issues and Challenges of Managing Human Resources in Multinational Organizations

Application of AHP to the Issues and Challenges of Managing Human Resources in Multinational Organizations

A typical AHP is composed of the following four-phases. 1) Construction of a hierarchy, which describes the problem. The overall goal is at the top of the structure, with the main attributes on a level below. 2) Derive weights for the lowest-level attributes by conducting a series of pair-wise comparisons in which each attribute on each level is compared with its 
family members in relation to their significance to the parent. However, to compute the overall weights of the lowest level, matrix arithmetic is required. 3) The options available to a decisionmaker are scored with respect to the lowest level attributes. Similarly, the pair-wise comparison approach is used. 4) Adjusting the options' scores to reflect the weights given to the attributes, and adding the adjusted scores to produce a final score for each optimum (RoperLowe and Sharp 1990). The hierarchy structure is used in the issues and challenges of crossborder and supply chain management, including corruption and bribery, exchange rates, logistics and customs regulations, political stability and transportation risks and costs.

\section{Pairwise comparison matrix $A$}

The pairwise comparisons represent the element that dominates or influences the order. The AHP is used to quantify subject matter experts' judgments shown as an $n-b y-n$ matrix below.

$\mathrm{A}=\left[\mathrm{a}_{i j}\right]=\left[\begin{array}{cccc}1 & a_{12} & \ldots & a_{i n} \\ 1 / a_{12} & 1 & \ldots & a_{2 n} \\ \cdot & \cdot & \cdot & \cdot \\ \cdot & \cdot & \cdot & \cdot \\ \cdot & \cdot & \cdot & \cdot \\ 1 / a_{1 n} & 1 / a_{2 n} & \ldots & 1\end{array}\right]=\mathrm{w}_{\mathrm{i}} / \mathrm{w}_{\mathrm{j}}=$
$\left[\begin{array}{cccc}w_{1} / w_{2} & w_{1} / w_{2} & \ldots & w_{1} / w_{n} \\ w_{2} / w_{1} & w_{2} / w_{2} & \ldots & w_{2} / w_{n} \\ \cdot & \cdot & \cdot & \cdot \\ \cdot & \cdot & \cdot \\ w_{n} / w_{1} & w_{n} / w_{2} & \ldots & w_{n} / w_{n}\end{array}\right]$

If $c_{p}$ is judged to be of equal importance as $c_{p}$ then $\left(\mathrm{a}_{i j}\right)=1$; If $\mathrm{c}_{i}$, is judged to be more important than $c_{j}$ then $\left(a_{i j}\right)>1$; If $c_{j}$ is judged to be less important than $c_{j}$ then $\left(a_{i j}\right)<1 ;\left(a_{i j}\right)=$ $1 / \mathrm{a}_{j p}(i, j=1,2,3, \ldots, n), \mathrm{a}_{i j} \neq 0$. Where matrix A represents a reciprocal matrix, $a_{i j}$ is the inverse of the entry $\mathrm{a}_{k j}$ which indicates the relative importance of $C_{i}$ compared with attribute $C_{j}$ For example, $\mathrm{a}_{12}=3$ indicates that $\mathrm{C}_{1}$ is 3 times as important as $\mathrm{C}_{2}$. In matrix $\mathrm{A}$, it becomes the case of assigning the $n$ elements $C_{1}, C_{2}, C_{3} \ldots C_{n}$ a set of numerical weights $W_{1}, W_{2}, W_{3} \ldots W_{n}$ representing the experts' judgments. If $A$ is a consistency matrix, the links between weights $\mathrm{W}_{\mathrm{i}}$ and judgments $\mathrm{a}_{\mathrm{ij}}$ are given by $\mathrm{W}_{\mathrm{i}} / \mathrm{W}_{\mathrm{j}}=\mathrm{a}_{\mathrm{ij}}$ (for $\mathrm{i}, \mathrm{j}=1,2,3 \ldots \mathrm{n})$.

\section{Eigenvalue and Eigenvector}

Saaty (1990) recommended that the maximum eigenvalue, ${ }^{\text {max }}$ is be determined as

$$
{ }_{\text {max }}=\sum_{j=1}^{n} a_{i j} W_{j} / W_{i}
$$

Where $\bullet_{\max }$ is the principal or maximum eigenvalue of positive real values in judgment matrix, $W_{j}$ is the weight of $f^{\text {th }}$ factor, and $W_{i}$ is the weight $I^{\text {th }}$ factor. If $A$ represents consistency matrix, eigenvector $\mathrm{X}$ can be determined as

$$
\left(A-{ }_{\max }\right) \mathrm{X}=0
$$

\section{Consistency test}

Both AHP and Expert Choice Software do not impose on the firm to be perfectly consistent. Rather, a consistency test is required to evaluate the degree of consistency as well as each judgment once the priorities are determined. The consistency index $(\mathrm{CI})$ and consistency ratio (CR) are employed to check for the consistency associated with the comparison matrix. To be sure that the priority of elements is consistent, the maximum eigenvector or relative weights $\left({ }_{\max }\right)$ can be determined. Specifically, CI for each matrix order $n$ is determined by using (3):

$$
\mathrm{CI}=\left(\bullet_{\max }-\mathrm{n}\right) / \mathrm{n}-1
$$

Where $n$ is the matrix size or the number of items to compare in the matrix. Based on (4), the consistency ratio (CR) can be determined as:

$$
\mathrm{CR}=\mathrm{CI} / \mathrm{RI}=\left[\left(\bullet_{\max }-\mathrm{n}\right) / \mathrm{n}-1\right] / \mathrm{RI} .
$$

CR is acceptable, if its value is less than or equal to 0.10 . If it is greater than 0.10 , the judgment matrix will be judged inconsistent. To rectify the judgment matrix that is inconsistent, decisionmakers' judgments should be reviewed and improved. Table 1 is the RI representing average 
consistency index over a number of random entries of same order reciprocal matrices.

Table1. Saaty's reference values of RI for different numbers of $n$

\begin{tabular}{lrrrrrrrrr}
\hline $\mathrm{n}$ & 2 & 3 & 4 & 5 & 6 & 7 & 8 & 9 & 10 \\
\hline RI & 0 & 0.58 & 0.90 & 1.12 & 1.24 & 1.32 & 1.41 & 1.45 & 1.51
\end{tabular}

\section{Overall/composite priority}

The composite priority score of the alternatives is determined by multiplying the relative priority of an alternative by the relative priorities of the corresponding criteria and added over all criteria.

Specifically,

$$
\mathrm{S}_{i}=\sum_{j=}^{n} \mathrm{w}_{\mathrm{j}} \mathrm{p}_{i j} \text { for } i=1,2 \ldots \mathrm{n}
$$

Where $S_{i}$ is the composite score for the $I^{\text {th }}$ alternative conflict management strategy, $\mathrm{p}_{i j}$ is the score of the $I^{\text {th }}$ alternative conflict management strategy with respect to the ${ }_{j}^{\text {th }}$ sales process attribute, and $\mathrm{w}_{j}$ is the priority weight of the $f^{\text {the }}$ marketing-sales relationship conflicts attribute in the second level.

\section{Data Collection Discussion}

Data were collected from three MNEs with more than 10,000 employees operating in an emerging economy. The researchers leveraged a combination of literature review and interview of senior HR managers to validate the challenges of managing human resources within the focal
MNEs. Based on the preceding and Figure 1, the researchers developed a survey questionnaire to facilitate pairwise comparisons between the major constructs in level 2 and between the alternatives in level 3 with respect to each of the major criterion. The researchers corrected the recommended changes on the survey questionnaire. The revised questionnaire were then sent to the senior HR managers to provide their expert judgments. Essentially, they provided responses to several pairwise comparisons, where two categories at a time were compared with respect to the goal.

For determining the number of judgments, $\mathrm{n}(\mathrm{n}-1) / 2$ was used, where $\mathrm{n}=$ number of criteria or attributes. It took a total of 10 judgments (i.e., [5(5-1)]/2 for the identified major criteria in the middle level of Figure 1 to complete the pairwise comparisons. For the alternatives strategies in the last level of Figure 1, it took a total of 6 judgments (i.e., [4(4-1)]/2 to complete the pairwise comparisons. The other entries were ones (1) along the diagonal as well as the reciprocals of the 10 judgments. To derive estimates of the criteria priorities, the researchers used the data reported in the matrix.

\section{RESULTS AND DISCUSSIONS}

- $\mathrm{CA}=$ Cultural Area

- ES = Economical Situation

- MS = Market Labor Situation

- LS = Legislation System

- PI = Political Issues

Table 1: Pairwise comparison matrix for the five attributes

\begin{tabular}{|l|r|r|r|r|r|}
\hline & CA & ES & MS & LS & PI \\
\hline CA & 1 & 1.528553544 & 1.44224957 & 1.817120593 & 1.912931183 \\
\hline ES & 1.528553544 & 1 & 1 & 1.169607095 & 3.301927249 \\
\hline MS & 1.44224957 & 1 & 1 & 1 & 1.44224957 \\
\hline LS & 1.817120593 & 1.169607095 & 1 & 1 & 1.709975947 \\
\hline PI & 1.912931183 & 3.301927249 & 1.44224957 & 1.709975947 & 1 \\
\hline TOTAL & 7.70085489 & 8.000087888 & 5.88449914 & 6.696703635 & 9.367083949 \\
\hline
\end{tabular}


Table 2: Issues/Challenges selection Attribute Priority

\begin{tabular}{|l|l|l|l|l|l|l|l|}
\hline & CA & ES & MS & LS & PI & PRIORITY & RANK \\
\hline CA & 0.129855713 & 0.191067094 & 0.245093004 & 0.271345529 & 0.204218431 & 0.208315954 & 2 \\
\hline ES & 0.19849141 & 0.124998627 & 0.169937997 & 0.174654152 & 0.352503219 & 0.204117081 & 3 \\
\hline MS & 0.187284346 & 0.124998627 & 0.169937997 & 0.1493272 & 0.153969963 & 0.157103627 & 5 \\
\hline LS & 0.23596349 & 0.146199281 & 0.169937997 & 0.1493272 & 0.182551577 & 0.176795909 & 4 \\
\hline PI & 0.248405042 & 0.412736372 & 0.245093004 & 0.255345919 & 0.10675681 & 0.253667429 & 1 \\
\hline
\end{tabular}

$\max =\frac{5.127605+4.342726+5.336988+5.380054+6.312885}{5}=5.300052$

$\mathrm{CI}=\frac{\lambda \max -\mathrm{n}}{\mathrm{n}-1}=\frac{5.300052-5}{5-1}=0.075013$

$\mathrm{CR}=\frac{\mathrm{CI}}{\mathrm{RI}}=\frac{0.075013}{1.12}=0.066976$; less than 0.1 ; acceptable

Table 3. Synthesized Matrix for "Cultural Area”

\begin{tabular}{|l|r|r|r|r|r|r|}
\hline & HP & SH & SP & TD & PRIORITY & RANK \\
\hline HP & 0.378271431 & 0.057246635 & 0.181068953 & 0.144109099 & 0.19017403 & 4 \\
\hline SH & 0.106348827 & 0.203620173 & 0.543206858 & 0.250463535 & 0.275909848 & 2 \\
\hline SP & 0.378271431 & 0.61086052 & 0.181068953 & 0.207841287 & 0.344510548 & 1 \\
\hline TD & 0.13710831 & 0.128272671 & 0.094655236 & 0.397586079 & 0.189405574 & 3 \\
\hline TOTAL & 1 & 1 & 1 & 1 & 1 & \\
\hline
\end{tabular}

$\lambda \max =\frac{3.580442+5.372138+4.24204+3.23245}{4}=\frac{16.42707}{4}=4.106767$

$\mathrm{CI}=\frac{\lambda \max -\mathrm{n}}{\mathrm{n}-1}=\frac{4.106767-4}{4-1}=0.035589$

$\mathrm{CR}=\frac{\mathrm{CI}}{\mathrm{RI}}=\frac{0.035589}{0.9}=0.039543$; less than 0.1 ; acceptable

Table 4. Synthesized Matrix for "Economical situation"

\begin{tabular}{|l|l|l|l|l|l|r|}
\hline \multicolumn{7}{|c|}{ ES } \\
\hline & HP & SH & SP & TD & PRIORITY & RANK \\
\hline HP & 0.227033553 & 0.277473883 & 0.270482764 & 0.313149661 & 0.272034965 & 2 \\
\hline SH & 0.286044352 & 0.220231167 & 0.375084548 & 0.217125848 & 0.274621479 & 1 \\
\hline SP & 0.259888542 & 0.349595187 & 0.236288459 & 0.15657483 & 0.250586754 & 3 \\
\hline TD & 0.227033553 & 0.152699763 & 0.118144229 & 0.313149661 & 0.202756801 & 4 \\
\hline TOTAL & 1 & 1 & 1 & 1 & 1 & \\
\hline
\end{tabular}

$\lambda \max =\frac{4.071695+4.208445+4.386911+3.898745}{4}=\frac{16.5658}{4}=4.141449$ 
$\mathrm{CI}=\frac{\lambda \max -\mathrm{n}}{\mathrm{n}-1}=\frac{4.141449-4}{4-1}=0.04715$

$\mathrm{CR}=\frac{\mathrm{CI}}{\mathrm{RI}}=\frac{0.04715}{0.9}=0.052389$; less than 0.1 ; acceptable

Table 5. Synthesized Matrix for "Market Labor Situations"

\begin{tabular}{|l|l|l|l|l|l|r|}
\hline \multicolumn{7}{|c|}{ MS } \\
\hline & HP & SH & SP & TD & PRIORITY & RANK \\
\hline HP & 0.240741991 & 0.235967628 & 0.246692983 & 0.272681587 & 0.249021047 & 2 \\
\hline SH & 0.215200117 & 0.263974376 & 0.195800351 & 0.238209307 & 0.228296038 & 4 \\
\hline SP & 0.240741991 & 0.209516601 & 0.246692983 & 0.272681587 & 0.242408291 & 3 \\
\hline TD & 0.303315902 & 0.290541395 & 0.310813683 & 0.216427519 & 0.280274625 & 1 \\
\hline TOTAL & 1 & 1 & 1 & 1 & 1 & \\
\hline
\end{tabular}

$\lambda \max =\frac{4.211001+4.169054+4.231505+4.105649}{4}=\frac{16.71721}{4}=4.179302$

$\mathrm{CI}=\frac{\lambda \text { max }-\mathrm{n}}{\mathrm{n}-1}=\frac{4.179302-4}{4-1}=0.059767$

$\mathrm{CR}=\frac{\mathrm{CI}}{\mathrm{RI}}=\frac{0.059767}{0.9}=0.066408$; less than 0.1 ; acceptable

Table 6. Synthesized Matrix for "Legislation System”

\begin{tabular}{|c|c|c|c|c|c|c|}
\hline \multicolumn{7}{|c|}{ LS } \\
\hline & HP & $\mathrm{SH}$ & SP & TD & PRIORITY & RANK \\
\hline $\mathrm{HP}$ & 0.389778643 & 0.040111184 & 0.10518932 & 0.198820967 & 0.183475029 & 4 \\
\hline $\mathrm{SH}$ & 0.056066694 & 0.278855091 & 0.249431459 & 0.286749454 & 0.217775674 & 3 \\
\hline SP & 0.16437602 & 0.278855091 & 0.249431459 & 0.315608612 & 0.252067796 & 2 \\
\hline TD & 0.389778643 & 0.402178634 & 0.395947761 & 0.198820967 & 0.346681501 & 1 \\
\hline TOTAL & 1 & 1 & 1 & 1 & 1 & \\
\hline
\end{tabular}

$\lambda \max =\frac{3.63964+4.574598+4.354148+3.589393}{4}=\frac{16.15778}{4}=4.039445$

$\mathrm{Cl}=\frac{\lambda \max -\mathrm{n}}{\mathrm{n}-1}=\frac{4.039445-4}{4-1}=0.013148$

$\mathrm{CR}=\frac{\mathrm{CI}}{\mathrm{RI}}=\frac{0.013148}{0.9}=0.014609$; less than 0.1 ; acceptable 
Table 7. Synthesized Matrix for "Political Issues"

\begin{tabular}{|l|l|l|l|l|l|r|}
\hline \multicolumn{7}{|c|}{ PI } \\
\hline & HP & SH & SP & TD & PRIORITY & RANK \\
\hline HP & 0.292064519 & 0.212667743 & 0.202412998 & 0.144432033 & 0.212894323 & 3 \\
\hline SH & 0.292064519 & 0.212667743 & 0.334176674 & 0.330666924 & 0.292393965 & 1 \\
\hline SP & 0.255141723 & 0.30671996 & 0.231705164 & 0.262450522 & 0.264004342 & 2 \\
\hline TD & 0.160729238 & 0.267944555 & 0.231705164 & 0.262450522 & 0.23070737 & 4 \\
\hline TOTAL & 1 & 1 & 1 & 1 & 1 & \\
\hline
\end{tabular}

$\lambda \max =\frac{4.053092+4.024438+4.175678+4.248955}{4}=\frac{16.50216}{4}=4.125541$

$\mathrm{CI}=\frac{\lambda \max -\mathrm{n}}{\mathrm{n}-1}=\frac{4.125541-4}{4-1}=0.041847$

$\mathrm{CR}=\frac{\mathrm{CI}}{\mathrm{RI}}=\frac{0.041847}{0.9}=0.046497$; less than 0.1 ; acceptable

The synthesized matrices for all the five attributes are shown in Table 3 to Table 7 . The $\mathrm{CR}$ is acceptable if it does not exceed 0.1. The judgment matrix is considered inconsistent and unacceptable if it is more than 0.10 . Judgments should be reviewed and improved to obtain a consistent matrix. The overall priority is determined using equation the $\mathrm{P}(\mathrm{ai})=$ $\Sigma \operatorname{kwkPk}(\mathrm{ai})$. Table 8 was computed to find the most important International Human Resource practices to solve the issues and challenges of managing $\mathrm{HR}$ in multinational organizations. Training and development has the highest mean weight of 0.244689306, followed by HR planning, staffing policies, and standardized HRM as shown in Table 8 below. Thus, we can conclude that training and development is the overall most important HR practice when managing Human Resources in Multinational companies.

Table 8. Attribute priorities used in the ranking model

\begin{tabular}{|l|r|c|c|c|c|r|r|}
\hline & \multicolumn{1}{|c|}{ CA } & ES & MS & LS & PI & & \\
\hline & 0.208315954 & 0.204117081 & 0.157103627 & 0.176795909 & 0.253667429 & PRIORITY & RANK \\
\hline HP & 0.19017403 & 0.272034965 & 0.249021047 & 0.183475029 & 0.212894323 & 0.220707367 & 2 \\
\hline SH & 0.27590948 & 0.274621479 & 0.228296038 & 0.217775674 & 0.292393965 & 0.26207009 & 4 \\
\hline SP & 0.344510548 & 0.250586754 & 0.242408291 & 0.252067796 & 0.264004342 & 0.27253316 & 3 \\
\hline TD & 0.189405574 & 0.202756801 & 0.280274625 & 0.346681501 & 0.23070737 & 0.244689306 & 1 \\
\hline & & & & & TOTAL & & 1 \\
\hline
\end{tabular}

\section{CONCLUSION}

Although globalization unites different characteristics in the world, different countries still adopt some differences in their business activities management and more precisely in managing HR (Brewster, Sparrow, \& Harris, 2005; Ferner, 1997). The mergers and acquisitions of emerging economies in developed markets reveals that there is a greater need to understand the how MNCs of emerging economies diffuse and coordinate 
their managerial practices. Research made on IHRM has mainly focused on western thinking rather than cross-pollination (Wright, Snell, \& Dyer, 2005).

Simply, multinationals strive to have a balance between growing globally and responding locally by adopting rules and practices on their international human resources. Factors such as country of origin, local and dominance influence the IHRM approaches operated by a multinational. Also, internal organizational factors such as related HRM capabilities, links and relationships within them as well as the way they are involved affect the type of approach of IHRM and what policies and practices are implemented (Chung et al., 2012). However, not all HRM practices are adapted similarly, some are more pressured to adapt to the local environment, whereas other are subject to internal stability.

The proposed AHP system can be used to support multinational companies to determine the attributes and the issues/challenges of managing their HR internationally and what are the best HR practices to solve these issues. This paper demonstrates how the AHP system can be used to support the decision in managing HR in MNCs and extends the collection of current body literature on the application of AHP algorithm in the HR department.

\section{REFERENCES}

Analoui, F. (1999): Effective Human Resource Development: A Challenge for Devel- oping Countries. Aldershot: Ashgate Publishing.

Brewster, C. and Scullion, H. (1997). A review and agenda for expatriate HRM. Human Resource Management Journal, 7(3), 32-41.

Brewster, C. et al. (1997): Integration and Assignment: a Paradox in Human Resource Management. Journal of International Management, 3 (1), pp. 1 - 23.

Brewster, C., Sparrow, P., Vernon, G., \& Houldsworth, E. (n.d.). International Human Resource Management Brewster. Retrieved November 1, 2016.

Chang, E., \& Taylor, S. M. (1999). Control in multinational corporations (MNCs): The case of Korean manufacturing subsidiaries. Journal of Management. 25(4): 541.
Chang, Y. Y., Mellahi, K., \& Wilkinson, A. (2009a). Control of subsidiaries of MNCs from emerging economies: The case of Taiwanese MNCs in the UK. The International Journal of Human Resource Management. 20(1): 7595.

Chang, Y. Y., Mellahi, K., \& Wilkinson, A. (2009b). Tensions Arising from Process of Transferring HRM Practices Across Borders: The case of Taiwanese MNCs in the UK In K. Ibeh \& S. Daviess (Eds.), Contemporary Challenges in International Business (pp.6879). Basingstoke: Palgrave Macmillan.

Chang, E., \& Taylor, S. M. (1999). Control in multinational corporations (MNCs): The case of Korean manufacturing subsidiaries. Journal of Management. 25(4): 541.

Chang, Y. Y., Wilkinson, A., \& Mellahi, K. (2007). HRM strategies and MNCs from emerging economies in the UK. European Business Review. 19(5): 404-419.

Chung, C., \& Furusawa, M. (2015). The HRM of Foreign MNCs Operating in Europe. Retrieved October 26, 2016.

Cherrington, D. (1983): Personnel Management. Dubuque, Iowa.

Chew, I., \& Zhu, W. (2002). Factors influencing Singapore managers' career aspiration in international assignments. Career Development International. 7(2): 96.

Chung, C., Bozkurt, O., and Sparrow, P. (2012) 'Managing the duality of IHRM: Unravelling the strategy and perceptions of key actors in South Korean MNCs', The International Journal of Human Resource Management, 23, 11: 2333-53.

Collings, D., Morley, M., Turner, T., \& Wallace, J. (2007). Human Resource Practices in Multinational Companies in Ireland: A Large Scale Survey. Retrieved November 1, 2016.

Collings, D., Morley, M. and Gunnigle, P. (2008) 'Composing the top management team in the international subsidiary: Qualitative evidence on international staffing in US MNCs in the Republic of Ireland', Journal of World Business, 43, 2:197-212.

Contractor, F. J., Kumar, V., \& Kundu, S. K. (2007). Nature of the relationship between international expansion and performance: 
The case of emerging market firms. Journal of World Business. 42: 401-417.

Cox, A. (2014). Human resource management in multinational companies. Retrieved November 1, 2016.

Evans, P., Pucik, V., and Björkman, I. (2011) The Global Challenge: International Human Resource Management, Second Edition, New York: McGraw Hill-Irwin.

Dowling, P.J., Welch, D.E. and Schuler, R.S. (1999). International Dimensions of Human Resource Management, 3rd edition. Cincinnati: SouthWestern College Publishing

Engardio, P., Arndt, M., \& Geri, S. (2006). Emerging Giants. Business Week, New York, 40, July, 31.

Farndale, E., \& Paauwe, J. (2005, March 3). The Role of Corporate HR Functions In Multinational ... Retrieved November 1, 2016.

Ferner, A. 1997. Country of origin effects and HRM in multinational companies. Human Resource Management Journal, 7(1): 19-37.

Ferner, A., Almond, P., Clark, I., Colling, T., Edwards, T., Holden, L., and Muller-Camen, M. (2004) 'Dynamics of central control and subsidiary autonomy in the management of human resources: Case-study evidence from US MNCs in the UK', Organization Studies, 25, 3:363-391.

Ferner, A., Almond, P., \& Colling, T. (2005). Institutional theory and the cross-national transfer of employment policy: the case of 'workforce diversity' in US multinationals. Journal of International Business Studies. 36(3): 304-325.

Ferner, A. (2009). HRM in Multinational Companies In A. Wilkinson, N.Bacon, T. Redman \& S. Snells (Eds.), The Sage Handbook of Human Resource Management (pp.539-558). Thousand Oaks, CA: Sage.

Glover, L., \& Wilkinson, A. (2007). Worlds colliding: the translation of modern management practices within a UK based subsidiary of a Korean-owned MNC.

Gooderham, P. N., Nordhaug, O., \& Ringdal, K. (1999). Institutional determinants of organizational practices: Human resource management in European firms.

Administrative Science Quarterly. 44: 507531.

Guest, D. and Conway, N. (2001) Public and Private Perceptions of the Psychological Contract. London. CIPD.

Gullien, \& Garcia -Canal, E. (2009). The American model of The multinational firm and the new multinationals from emerging economies. Academy of management perspectives. 23(2): 23-35.

Gustaffson, L. (1990): Promoting Flexibility through Pay Policies - Experiences from the Swedish National Administration. Flexible Personnel Management in the Public Services. Paris: OECD.

Harzing, A. W. (2001) 'Who's in charge? An empirical study of executive staffing practices in foreign subsidiaries', Human Resource Management, 40, 2: 139-158.

Harzing, AW \& Sorge, A M, (2003), 'The relative impact of country-of-origin and universal contingencies on internationalization strategies and corporate control in multinational enterprises: World-wide and European perspectives', Organisation Studies, vol. 24, no. 2, pp. 187-214.

Hendry, C. (1994): Human Resource Strategies for International Growth. London: Routledge.

Hentze, J. (1989): Personalwirtschaftslehre. Bern.

Hilb, M. (2000): Transnationales Management der Human-Ressourcen. Berlin: Luchterhand.

Hofstede, G. (1984). Culture's Consequences: International Differences in Work-Related Values. Beverly Hills, CA Sage Publications.

Hofstede, G. (1988): Cultures and Consequences - International Differences in Work Related Values. Beverly Hills.

Hofstede, G. (1991): Cultures and Organizations: Software of the Mind. London: McGraw-Hill

Hofstede, G. (2007). Asian management in the 21st century. Asia Pacific Journal of Management. 24(4): 411-420.

House, R. et al. (1998): The Global Leadership and Organizational Behavior Effectiveness Research Program. Philadelphia. 
Hussain, A., \& Jian, C. (1999). Changes in China's industrial landscape and their implications. International Studies of Management \& Organization. 29(3): 5-20

Kopp, R. (1994) 'International human resource policies and practices in Japanese, European, and United States multinationals', Human Resource Management, 33, 4: 581-599.

Kammel, A. and Teichelmann, D. (1994): Internationaler Personaleinsatz. München.

Lall, S. (1983). The new multinationals: The spread of third world enterprises. Chichester: Wiley.

Larsen, H. / Brewster, C. (2000): Human Resource Management in Northern Europe. Trends, Dilemmas and Strategies. In: Brewster, C. / Larsen, H. (eds.) (2000): Human Resource Management in Northern Europe. Trends, Dilemmas and Strategy. Black- well, pp. 1 - 23.

Laurent, A. (1986): The Cross-Cultural Puzzle of International Human Resource Management. in: Human Resource Management, 25 (1), pp.91 - 102.

Lawrence, P.R. and Lorsch, J.W. (1967). Organization and Environment. Cambridge, MA: Harvard University Press.

Legge, K. (1989): Human Resource Management: a Critical Analysis. In: Storey, J. (Ed.): New Perspectives on Human Resource Management. London: Routledge.

Mendenhall, M., Kuhlmann, T.M., Stahl, G.K. and Osland, J.S. (2002). Employee development and expatriate assignments. In Gannon, $M$. and Newman, K. (eds) Handbook in Crosscultural Management. London: Blackwell

Miller, P. (1989): Strategic HRM: what it is and what it isn't. Personnel Management, Feb., pp. $46-51$.

Nitsche, S., Hilb, M., \& Brewster, C. (n.d.). Human Resource Management of Multinational Organisations ... Retrieved November 1 , 2016.

Ngo, H.-Y., Turban, D., Lau, C.-M., \& Lui, S.-Y. (1998). Human resource practices and firm performance of multinational corporations: influences of country of origin. The International Journal of Human Resource Management. 9(4): 632-652.
Noble, C. (1997). International comparisons of training policies. Human Resource Management Journal, 7(1), 5-18.

Ohmae, K. (1990). The borderless world: Power \& strategy in the interlinked economy. London: Collins.

Peterson, R.B., Napier, N. and Shim, W.S. (1996). Expatriate management: the differential role of national multinational corporation ownership. The International Executive, 38(4), 543-562.

Pieper, R. (1990): Managementtraining in Osteuropa. Wiesbaden.

Pucik, V. and Katz, J.H. (1986). Information, control human resource management in multinational firms. Human Resource Management, 25, 121-32.

Punnett, B.J. and Ricks, D.A. (1992). International Business. Boston: PWS Kent.

Purcell, J. (1988): The Structure and Function of Personnel Management. Beyond the workplace. Managing Industrial Relations in the Multi-Establishment Enterprise. Oxford.

Purcel, J. (1989): The Impact of Corporate Strategy on Human Resource Management. In:

Purcell, J. (2001): The Meaning of Strategy in Human Resource Management: A Criti- cal Text. In: Storey, J. (ed.) (2001): Human Resource Management. London: Thomson Learning.

Rose, R. C., \& Kumar, N. (2007). The transfer of Japanese-style HRM to subsidiaries abroad. Cross Cultural Management. 14(3): 240-253.

Rosenzweig, J \& Nohria, N 1994, 'Influences on human resource management practices in multinational corporations', Journal of International Business Studies, Second quarter, pp. 229-251.

Rosenzweig, P.M. (2006) 'The dual logics behind international human resource management: pressures for global integration and local responsiveness', in G.K. Stahl and I. Björkman (eds.), Handbook of Research in International Human Resource Management, pp. 36-48, Cheltenham: Edward Elgar

Sergio,R and Rylova, M. (2018) .Employee 
Engagement and Empowerment as Gateway Towards Retention:The Case of Volkswagen Group, Journal of Eastern European and Central Asian Research, 5(2),pp.120-127.

Schein, E. (1985): Organizational Culture and Leadership: A Dynamic View. San Francisco.

Scherm, E. (1999): Internationales Personalmanagement. München: R. Oldenbourg Verlag.

Schuler, R. S., Dowling, P. J., \& DeCieri, H. (1993). An integrative framework of strategic international human resource management. Journal of Management, 19: 419-460.

Schuler, R.S. and Rogovsky, N. (1998). Understanding compensation practice variations across firms: the impact of national culture. Journal of International Business Studies, 29, 159-177.

Schuler, R. S., Budhwar, P. S., \& Florkowski, G. W. (2002). International human resource management: review and critique. IJMR, 4(1).

Scullion, H. and Brewster, C. (2002) 'The management of expatriates: messages from Europe?', Journal of World Business, 36, 4:346-365.

Sherman et al. (1996): Managing Human Resources. Cincinati.

Sisson, J. / Storey, J. (2000): The Realities of Human Resource Management. Buckingham: Open University Press.

Storey, J. (ed.) (1989): New Perspectives On Human Resource Management. Lon- don: Routledge.

Storey, J. (ed.) (1995): Human Resource Management: A Critical Text. London: Routledge.

Storey, J. (ed.) (2001b): Human Resource Management: A Critical Text. London: Thomson Learning.

Smith, C., \& Meiskins, P. (1995). System, Society and Dominance Effects in Cross-National Organisational Analysis. Work, Employment and Society. 9(2): 241-308.

Tayeb, M (1998), 'Transfer of HRM practices across cultures: an American company in Scotland', The International Journal of Human Resource Management, vol. 9, no. 2, pp. 332-358.
Taylor, S, S Beechler, and N Napier. 1996. Toward an integrative model of strategic international human resource management. Academy of Management Review 21, no. 4: 959-85.

Thite, M. (2004). Managing People in the New Economy: Targeted HR Practices that Persuade People to Unlock their Knowledge Power. New Delhi ; Thousand Oaks, Calif: Response Books.

Thite, M., Wilkinson, A., \& Shah, D. (n.d.). Internationalization \& HRM Strategies across

Subsidiaries in Multinational Corporations from Emerging Economies- A Conceptual Framework. Retrieved November 1, 2016.

Tiwari, N. (2013). Managing Human Resources in International Organizations. Retrieved November 1, 2016.

Torrington, D. / Hall, L. (1995): Personnel Management: HRM in Action. London: Prentice Hall.

Trompenaars, F. (1993): Riding the Waves of Culture. London: Economist Books.

Tung, R.L. (1982). Selection and training procedures of US, European, and Japanese multinationals. California Management Review, 25, 57-71.

Tyson, S. (1987): The Management of Personnel Function. Journal of Management Studies, 24, Sept., pp. 523 - 532.

Tyson, S. (2002): The Changing Nature of Human Resource Management. In: Analoui, F. (ed.) (2002): The changing patterns of human resource management. Aldershot: Ashgate Publishing, pp. $1-12$.

Wells, L. T. (1983). Third world multinationals: The rise of foreign investment from developing countries. Cambridge, MA: The MIT Press.

Wong, N. (2000). Mark your calendar! Important tasks for international HR workforce. Costa Mesa, 79(4), 72-74.

Wright, P. M., Snell, S. A., \& Dyer, L. (2005). New models of strategic HRM in global context. The International Journal of Human Resource Management. 16(6): 875-881. 


\section{ABOUT THE AUTHOR}

Chris I. Enyinda, email: i.enyinda@ajman.ac.ae

Dr. Chris I. Enyinda graduated with a doctoral degree in Transportation and Logistics graduate from North Dakota State University and a Ph.D. in Applied Economics from the University of Tennessee. He is currently a Professor of Marketing and MBA at Ajman University. He has been at the academy for more than three decades, spearheaded workshops, published articles and presented papers at various international conferences. He was awarded the following recognitions: Outstanding Global Research Award, Best Professor in Marketing and International Business, Best Paper Award, Best Research Award, and many others. Prior to his engagement in UAE, he was a Professor at A \& M - Alabama University, USA.

Dr. Maria Jade Catalan-Opulencia holds a Ph.D. in Management from the University of Liverpool. She is a Professor of Management at Ajman University. Her main research interests include entrepreneurship, human resource management, women and leadership. She had published articles, edited and authored academic resource materials, reviewed and presented papers at international conferences. She garnered the Best Abstract in 2016 and Best Paper Award on 2015. She had presented papers in Cambridge University and Oxford University respectively. She attended the Case Method Teaching Seminar at Harvard University in 2013. Dr. Opulencia has served the academe for more than two decades.

Dr. Mervyn Misajon obtained his doctoral degree from Michigan State University. He possesses 44 years of teaching experience in both Business and Public Management at the bachelor, master and doctoral levels in various academic institutions. He has extensive academic management experience both in his home country and abroad. He was Dean of Students, Dean of School of Development Management, Dean of the College of Management, Project Manager with the rank of Assistant Secretary for the Office of Higher Education of Papua New Guinea. He acted as a consultant and resource knowledge source for non-government and government organizations. Currently, he is a Professor of Management at Ajman University.

Dr. Gurumurthy Kalyanaram holds a Ph.D. in Management of Science and Industrial Organization Economics. He is a graduate of the Massachusetts Institute of Technology (MIT). He was presented with an MIT Harold Lobdell Award and is the recipient of various awards and commendations. $\mathrm{He}$ is an Academic and Research Adviser, Editor-inChief of NMIMS University, India. Currently, he is an Editor-in-Chief, of the Management Review and Economics and Public Policy Journal as well as the US Editor of the International Journal of Learning and Change (Scopus). He is a Professor (Parttime/Visiting) from the City University of New York and New Jersey Institute of Technology. Dr. Kalyanaram acts as a Research Professor and External Examiner at Tata Institute of Social Sciences (India), and in Montclair State University (USA). 